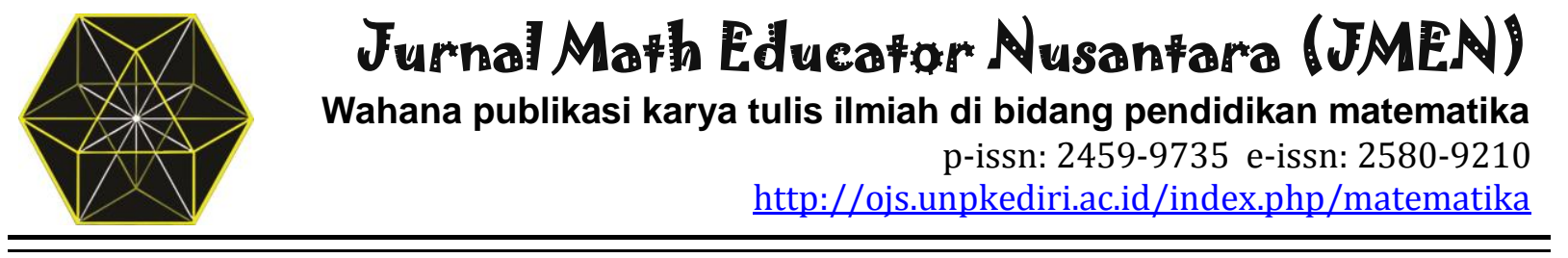

\title{
Penerapan model pembelajaran think pare share untuk meningkatkan motivasi dan hasil belajar siswa
}

\author{
Komari \\ Madrasah Tsanawiyah Negeri 4 Nganjuk, Dusun Termas Desa Jekek Kecamatan Baron Kabupaten \\ Nganjuk 64394, Indonesia \\ Email : komari1966@gmail.com
}

Article received: 29 Okt 2019, article revised: 14 Des 2019, article published: 17 Des 2019

\begin{abstract}
Abstrak : Tujuan penelitian ini adalah untuk meningkatkan motivasi belajar matematika dan hasil belajar matematika kelas VIII MTs Negeri 4 Nganjuk, dengan menggunakan model pembelajaran think pare share (TPS). Penelitian ini merupakan penelitian tindakan kelas yang terdiri dari empat fase, yaitu perencanaan, pelaksanaan, pengamatan dan refleksi. Teknik penelitian yang digunakan yaitu tes hasil belajar siswa, dan angket untuk menggali data motivasi belajar siswa. Hasil penelitian menunjukan adanya peningkatan motivasi belajar siswa dan hasil belajar matematika siswa, dengan bukti prosentase motivasi belajar siswa pada siklus pertama adalah 72,74\% menjadi 86,28\% siklus kedua. Hasil belajar dari siklus I ketuntasan klasikalnya 65,38\% dengan nilai rata-rata siswa 74,04 meningkat menjadi $80,77 \%$ dengan rata-rata nilai siswa sebesar 77,31 pada siklus II.
\end{abstract}

Kata Kunci: Model Pembelajaran, Think Pare Share, TPS, Motivasi, Hasil Belajar, Matematika

\section{Application of think pair share learning models to improve student motivation and learning outcomes}

\begin{abstract}
The purpose of this study is to increase the motivation to learn mathematics and mathematics learning outcomes of VIII grade MTs Negeri 4 Nganjuk, using the think pare share learning model. This research is a class action research consisting of four phases, namely planning, implementing, observing, and reflecting. The research technique used was a student learning achievement test and a questionnaire to explore student learning motivation data. The results showed an increase in student motivation and student learning outcomes in mathematics, with evidence of the percentage of student motivation in the first cycle was $72.74 \%$ to $86.28 \%$ in the second cycle. The learning outcomes of the classical period I mastery $65.38 \%$ with an average value of 74.04 students increased to $80.77 \%$, with an average student score of 77.31 in the second cycle.
\end{abstract}

Keywords: Learning Model, Think Pare Share, TPS, Motivation, Learning Outcomes, Mathematics

CITATION FORMATS: Komari, K. (2019). Penerapan model pembelajaran think pare share untuk meningkatkan motivasi dan hasil belajar siswa. Jurnal Math Educator Nusantara: Wahana Publikasi Karya Tulis IImiah Di Bidang Pendidikan Matematika, 5(2), 198-204. https://doi.org/10.29407/jmen.v5i2.13848 


\section{PENDAHULUAN}

Pendidikan merupakan suatu upaya manusia untuk mengembangkan pengetahuan dimiliki dengan tujuan untuk membentuk kepribadian dan keterampilan. UU No. 20 tahun 2003 menjelaskan, pendidikan adalah usaha sadar dan terencana untuk mewujudkan suasana belajar dan proses pembelajaran agar peserta didik secara aktif mengembangkan potensi dirinya utuk memiliki kekuatan spiritual keagamaan, pengendaian diri, kepribadian, kecerdasan, akhlak mulia, serta keterampilan yang diperlukan dirinya, masyarakat, bangsa dan Negara. Salah satu perkembangan yang dimaksudkan adalah perkembangan matematika. Matematika merupakan ilmu dari segara ilmu, atau bapaknya ilmu, karena matematika dasar ilmu yang berguna untuk kehidupan. Ironisnya tidak sedikit siswa yang memadang bahwa matematika suatu pelajaran yang sulit. Anggapan itu akan mempengaruhi motivasi belajar siswa terutama dalam pembelajaran matematika. Pembelajaran matematika diperlukan suatu motivasi atau dorongan dalam diri siswa utnuk menimbulkan rasa ingin tahu dalam belajar, sehingga dapat mengarah pada peningkatan prestasi belajar matematika.

Pengamatan peneliti selama mengajar di MTs Negeri 4 Nganjuk mengungkap kurannya motivasi belajar siswa terhadap materi matematika yang diajarkan, sehingga menyebabkan penurunan terhadap hasil belajar matematika. Rendahnya hasil belajar dapat dilihat dari nilai ulangan harian terahir pada kelas VII, yang rata-rata nilainya 69,42 dan secara klasikal hanya $61,54 \%$. Nilai ini sangat rendah jika dibandingkan dengan KKM yang sudah ditentukan yaitu nilai $K K M \geq 70$, dan secara klasikal mendapatkan $\geq 75 \%$. Siswa kurang bersemangat dalam mengikuti pelajaran. Komunikasi antar siswa masih kurang terlihat, ini terlihat ketika berkolaborasi siswa masih suka mengerjakan sendiri tanpa berdiskusi dengan teman sekelompoknya.

Menyikapi permasalahan yang dihadapi peneliti, perlu adanya suatu model pembelajaran yang pas untuk meningkatkan motivasi dan hasil belajar matematika di MTs Negeri 4 Nganjuk. Model pembelajaran harus bisa mempermudah siswa untuk belajar matematika. Siswa tidak menjadi terbebani dalam belajar matematika. Guru yang profesional harus bisa memilih model pembelajaran yang cocok dengan karakter anak dan yang cocok dengan matari yang akan diberikan sehingga mampu meningkatkan motivasi dan hasil belajar matamatika siswa. Model pembelajaran yang bagus adalah model pembelajaran yang mampu meningkatkan minat siswa dalam belajar (Purwantari, 2016).

Model pembelajaran Think pare share (TPS) bisa menjadi pertimbangan untuk digunakan dalam pembelajan matamatika. Model pembelajaran TPS merupakan salah satu dari beberapa model pembelajaran kooperatif, dimana siswa mampu berinteraksi dengan orang lain dengan cara berpasangan untuk berdiskusi untuk saling bertukar informasi (Jatmiko, 2015). Model pembelajaran TPS mampu meningkatkan kemampuan siswa dalam berpikir dan berkomunikasi, melalui diskusi sehinga akan terjadi komunikasi yang baik antar peserta didik, saling 
menyampaikan ide sebelum mereka mempresentasikan ke depan kelas. Penggunaan model pembelajaran TPS akan membuat suasana kelas akan menajdi hidup dan lebih ceria, sehingga dapat berpengaruh kepada proses belajar matamatika yang positif. Sehingga diharapkan muncul motivasi belajar matematika sehingga berpengaruhterhadap hasil belajar matematika siswa di MTs Negeri 4 Nganjuk.

Berdasarkan permasalahan diatas, peneliti tertarik untuk meningkatkan motivasi siswa dan hasil belajar siswa dengan menggunakan model pembelajaran Think pare share (TPS) di kelas VIII MTs Negeri 4 Nganjuk.

\section{METODE PENELITIAN}

Penelitian ini merupakan penelitian tindakan kelas (PTK). PTK merupakan penelitian yang dilakukan secara kolaborasi antara peneliti dan guru di dalam kelas untuk menyempurnakan atau meningkatkan praktik dan proses belajar (Susilo, 2007:16). Dalam penelitian ini guru juga bertindak sebagai peneliti, guru dibantu oleh rekan sejawat untuk mengamati perilaku dan motivasi subjek yang di teliti. Penelitian ini dilaksanakan dalam tiga siklus untuk mengetahui peningkatan hasil belajar siswa dan peningkatan motivasi belajar siswa setelah menerima pembelajaran matematika menggunakan TPS. Sampel penelitian adalah siswa kelas VIII MTs Negeri 4 Nganjuk. Prosedur penelitian yang digunakan adalah prosedur penelitian tindakan kelas yang dikembangkan oleh kemmis dan taggart (Arikunto, 2007: 131). Penelitian tindakan kelas ini terdiri dari empat fase pokok, yaitu perencanaan, pelaksanaan, pengamatan dan refleksi.

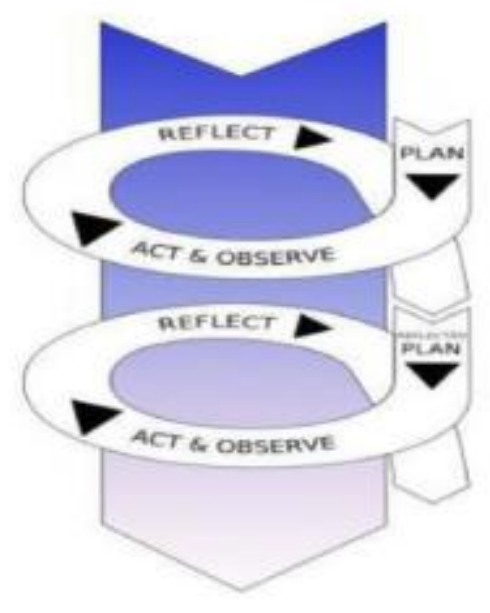

Gambar 1 Siklus pelaksanaan PTK model Kemmis dan MC Taggart

Teknik penelitian yang digunakan yaitu tes hasil belajar siswa, dan angket untuk menggali data motivasi belajar siswa. Indikator keberhasilan butuhkan peneliti untuk menentukan berlanjut atau tidaknya penelitian. Indikator yang digunakan dalam penelitian ini adalah motivasi belajar siswa dikatakan berhasil; jila mencapai prosentase $\geq 80 \%$. Seperti yang dikatakan Arikunto 
(2010:35), pembelajaran dikatakan sangat baik jika memperoleh prosentase $\geq 80 \%$. Siswa dinyatakan tuntas jika memperoleh nilai $K K M \geq 70$, dan secara klasikal mendapatkan $\geq 75 \%$. Batas ketuntasan ini sudah ditetapkan sesuai dengan peraturan sekolah.

\section{HASIL DAN PEMBAHASAN}

Penelitian ini terdiri dari 2 siklus, setiap siklus yang dilaksanakan terdiri dari 3 pertemuan. Jumlah subjek penelitian terdiri dari 26 orang yang merupakan siswa kelas VIII MTs Negeri 4 Nganjuk tahun ajaran 2019/2020. Hasil penelitian yang diperoleh adalah data motivasi siswa dan hasil belajar matematika siswa.

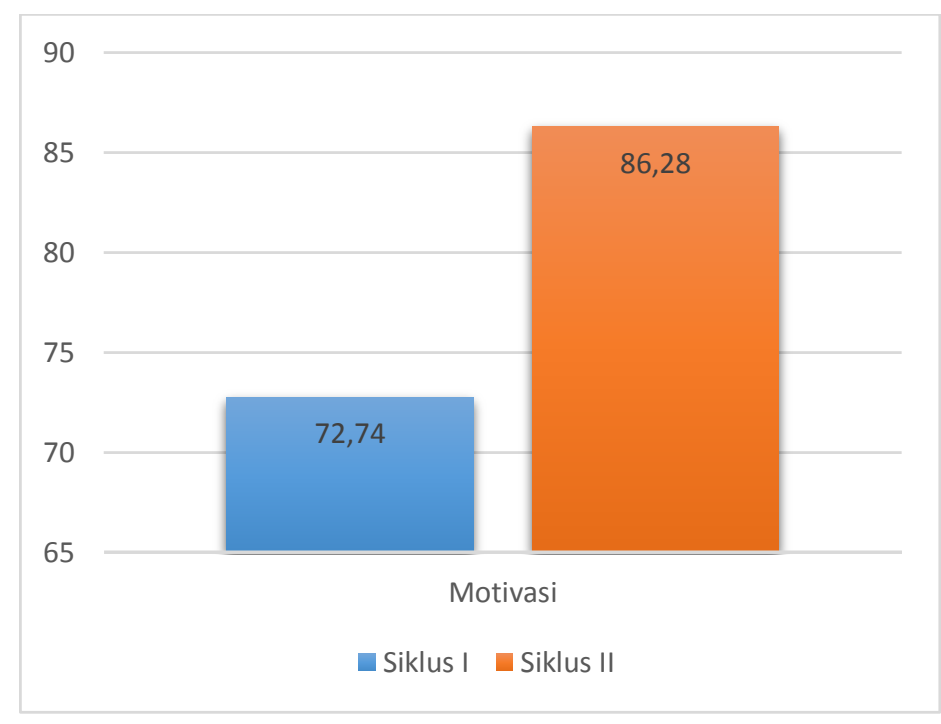

Gambar 1. Prosentase Motivasi Siswa

Dengan menerapkan model pembelajaran TPS. Prosentase motivasi belajar siswa pada siklus pertama adalah $72,74 \%$. Motivasi belajar siswa pada siklus kedua mendapatkan prosentase sebesar 86,28\% (Gambar 1). Ini menunjukan motivasi belajar siswa mengalami peningkatan dari siklus I ke siklus II. Hasil ini menunjukan peningkatan yang positif dan bagus serta melampaui target ketuntasan yang sudah ditentukan.

Tabel 1 . Presentasi Ketuntasan Klasikal

\begin{tabular}{lccc}
\hline & Rata-rata & Prosentase Ketuntasan Klasikal & Kriteria \\
\hline Siklus I & 74,04 & 65,38 & Sedang \\
Siklus II & 77,31 & 80,77 & Tinggi \\
\hline
\end{tabular}

Ketuntasan belajar secara klasikal pada pembelajaran matematika dengan menggunakan model pembelajaran TPS mengalami peningkatan. Pada siklus I ketuntasan klasikal 65,38\% 
dengan nilai rata-rata siswa 74,04. Hail ini terlihat belum memenuhi target ketuntasan klasikal yang sudah di tentukan yaitu sebesar 75\%, maka diperlukan tindakan perbaikan pada pembelajaran matematika pada siklus II. Hal klasikal pada siklus II menunjukan adanya peningkatan yaitu $80,77 \%$ dengan rata-rata nilai siswa sebesar 77,31 (tabel 1). Hasil ini sudah memenuhi target ketuntasan klasikal yang sudah di tentukan sebelumnya.

Hasil penelitian menunjukan adanya peningkatan motivasi belajar siswa dan hasil belajar matematika siswa. Karena penelitian ini sudah mencapai indikator keberhasilan yang di ditentukan, maka penelitian dapat dikatakatan berhasil. Ini terbukti adanya peningkatan motivasi dan hasil belajar matematika siswa MTs Negeri 4 Nganjuk, dan memenuhi indikator keberhasilan yang sudah ditentukan. Penelitian yang dilakukan sejalan dengan yang dilakukan oleh (Anggara, 2013; Suryani, 2013; Ahsani, 2014; Jatmiko, Santia dan Setyaningrum, 2016; Kurniasari dan Setyaningtyas, 2017) menyimpulkan bahwa model pembelajaran TPS dapat meningkatkan hasil belajar matematika. Hasil penelitian lain juga menjelaskan bahwa model pembelajaran TPS mampu meningkatkan motivasi belajar matematika siswa (Wulandari, 2015; Purwantari, 2016; Hafizhah, Isnani, dan Suwandono, 2019). Penelitian ini sesuai dengan pendapat Uno (2016), jika suatu motivasi belajar siswa meningkat, maka hasil belajar siswa juga ikut meningkat.

Keberhasilan penelitian tidak lepas dari upaya yang dilakukan oleh guru untuk menyempurnakan pembelajaran yang sudah terjadi di siklus I pada pembelajaran yang dilakukan pada siklus II. Kendala-kendala yang muncul di siklus I dengan menggunakan model pembelajaran TPS harus diselesaikan. Beberapa kendala yang muncul adalah (1). Sulitnya mengontrol siswa, karena pembelajaran TPS masih awam dipergunakan oleh siswa. (2). Siswa masih malu untuk menunjukan kemampuan, terutama dalam mempresentasikan hasil pekerjaannya serta pada saat siswa diberikan kesempatan untuk bertanya. (3) terdapat siswa kurang bisa mengikuti alur pembelajaran, karena siswa tersebut kurang mengasah kemampuannya ketika masih di rumah sehingga tertinggal dengan teman-temannya. (4). Ketika diberikan tugas untuk mengerjakan lembar kerja, siswa masih ada yang suka mengganggu temannya, ini mengakibatkan kurang kondusifnya kelas. (5). Ketika berpasangan, siswa ada yang tidak mau berpasangan dengan teman sekelompoknya.

Kendala-kendala tersebut akhirnya di selesaikan dengan pembelajaran yang lebih komprehensif, menciptakan kelas yang lebih menyenangkan, serta penguasaan kelas yang lebih di siklus II. Hasilnya dapat dilihat bahwa terdapat peningkatan, baik dari motivasi belajar siswa maupun dari hasil belajar matematika siswa. 


\section{KESIMPULAN}

Hasil penelitian menunjukan adanya peningkatan motivasi belajar siswa dan hasil belajar matematika siswa kelas VIII MTs Negeri 4 Nganjuk. Peningkatan ini terlihat pada bukti prosentase motivasi belajar siswa pada siklus I adalah 72,74\% menjadi $86,28 \%$ siklus II. Hasil belajar dari siklus I ketuntasan klasikalnya 65,38\% dengan nilai rata-rata siswa 74,04 meningkat menjadi 80,77\% dengan rata-rata nilai siswa sebesar 77,31 pada siklus II. Diharapkan hasil penelitian ini dapat menjadi salah satu referensi atau informasi tambahan dalam mengambil kebijakan untuk meningkatkan kempuan siswa.

\section{DAFTAR PUSTAKA}

Ahsani, E. L. F. (2014). Penerapan model kooperatif tipe think pair share untuk meningkatkan hasil belajar IPS pada siswa kelas V SD 1 Rejosari tahun 2013/2014. Skripsi. Pendidikan Guru Sekolah Dasar Fakultas Keguruan dan IImu Pendidikan. Universitas Muria Kudus.

Anggara, D. S. (2013). Peningkatan pembelajaran IPS melalui model think pair share dengan media CD pembelajaran pada siswa kelas III SD Negeri Kalibenteng 02 Semarang. Skripsi. PGSD. Universitas Negeri Semarang.

Arikunto, S. (2006). Prosedur penelitian suatu pendekatan praktik. Jakarta: PT Rineka Cipta Arikunto, S. (2010). Prosedur penelitian suatu pendekatan praktik. Jakarta: PT Rineka Cipta

Depdiknas. (2003). Undang-Undang RI nomor 20 Tahun 2003 tentang Sistem Pendidikan Nasional.

Hafizhah, N., Isnani, \& Suwandono. (2019). Keefektifan model pembelajaran TPS terhadap motivasi, kemampuan berpikir kritis, dan prestasi belajar matematika. Jurnal Pendidikan MIPA Pancasakti, 3(1), 61 - 67

Jatmiko, J. (2015). Eksperimentasi Model pembelajaran think-pair-share dengan modul (TpsM) Ditinjau dari kecerdasan interpersonal. Efektor, 26(2), 26-32, doi:10.29407/e.v2i2.87

Jatmiko, J., Santia,I., \& Setyaningrum, D. (2016). Eksperimen model pembelajaran think pair share ditinjau dari kecerdasan interpersonal peserta didik. Jurnal Math Educator Nusantara: Wahana Publikasi Karya Tulis IImiah di Bidang Pendidikan Matematika, 2(1), 85-93

Kurniasari, E. F., \& Setyaningtyas, E. W. (2017). Peningkatan hasil belajar IPS melalui penerapan model pembelajaran kooperatif tipe think pair and share (TPS) dengan teknik gallery walk. Journal of Education Research and Evaluation. 1 (2), 120-127. DOI: http://dx.doi.org/10.23887/jere.v1i2.10074

Purwantari, K. (2016). Upaya meningkatkan motivasi dan prestasi belajar matematika dengan model pembelajaran think pair and share (TPS). UNION: Jurnal Pendidikan Matematika, 4(2), 293-302. Doi: http://dx.doi.org/10.30738/.v4i2.448

Susilo. (2007). Penelitian tindakan kelas. Yogyakarta: Pustaka book. 
Uno, H. B. (2016). Teori motivasi \& pengukurannya. Jakarta: Bumi Aksara.

Wulandari, W. S. (2015). Pengaruh model pembelajaran kooperatif tipe think pair share dalam meningkatkan kemampuan komunikasi matematis dan motivasi belajar matematika siswa sekolah dasar: Penelitian kuasi eksperimen pada kelas IV di dua sekolah dasar negeri Kecamatan Leles Kabupaten Garut tahun ajaran 2014/2015. Disertasi. Universitas Pendidikan Indonesia.

Wulandari, W. S. (2015). Meningkatkan kemampuan komunikasi dan motivasi belajar matematika siswa sekolah dasar melalui pembelajaran kooperatif tipe think-pair-share. EduHumaniora: Jurnal Pendidikan 7(2),1-11 DOI: https://doi.org/10.17509/eh.v7i2.2710 